\title{
NATIONAL CENTER FOR EDUCATION STATISTICS
}

\author{
Statistics in Brief
}

May 2001

\section{Internet Access in U.S. Public Schools and Classrooms: $1994-2000$}

Contact:

Bernie Greene

202-502-7348

Authors:

Anne Cattagni

Elizabeth Farris

Westat
Since 1994, the National Center for Education Statistics (NCES) has surveyed public schools to measure what proportion of them are connected to the Internet. These annual surveys enable the U.S. Department of Education to monitor the progress made by public schools in providing access for all students and teachers to information technology in their classrooms and schools. In the fall of each academic year, a new nationally representative sample of approximately 1,000 public schools has been surveyed about Internet access and, since 1996, about the types of Internet connections used. In 2000, questions were also asked about access to the Internet at times outside of regular school hours and on "acceptable use policies."

How much progress have public schools made in connecting to the Internet?

By the fall of 2000, almost all public schools in the United States had access to the Internet: 98 percent were connected. In comparison, 35 percent of public schools had access to the Internet in 1994 (table 1). Unlike in previous years, there were virtually no differences in school access to the Internet by school characteristics (e.g., poverty level ${ }^{1}$ and metropolitan status) in 1999 or 2000.

The increase in Internet access over the years may have been aided by the allocation of funds through the Education rate (E-rate) program. The E-rate program was established in 1996 to make services, Internet access, and internal connections available to schools and libraries at discounted rates based upon the income level of the students in their community and whether their location is urban or rural. $^{2}$ As of February 28, 2001, $\$ 5.8$ billion has been committed to Erate applicants throughout the nation. ${ }^{3}$

\footnotetext{
${ }^{1}$ Throughout this report, poverty level is measured by the percentage of students eligible for free or reducedprice lunch.

${ }^{2}$ The poorest applicants receive the largest discounts ( 90 percent), and rural communities receive up to a 10 percent additional discount.

${ }^{3}$ The E-rate program funding commitment data were found at the Web site of the School and Libraries Division (SLD), Universal Service Administrative Company (http://www.sl.universalservice.org/whatsnew/).
}

U.S. Department of Education

Office of Educational Research and Improvement

NCES 2001-071 
Table 1.-Percent of public schools with Internet access, by school characteristics: 1994-2000

\begin{tabular}{|c|c|c|c|c|c|c|c|}
\hline \multirow{2}{*}{ School characteristic } & \multicolumn{7}{|c|}{ Public schools with Internet access } \\
\hline & 1994 & 1995 & 1996 & 1997 & 1998 & 1999 & 2000 \\
\hline 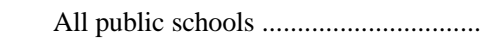 & 35 & 50 & 65 & 78 & 89 & 95 & 98 \\
\hline \multicolumn{8}{|l|}{ Instructional level ${ }^{1}$} \\
\hline 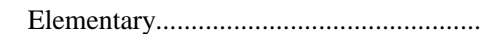 & 30 & 46 & 61 & 75 & 88 & 94 & 97 \\
\hline Secondary & 49 & 65 & 77 & 89 & 94 & 98 & ${ }^{4} 100$ \\
\hline \multicolumn{8}{|l|}{ School size } \\
\hline 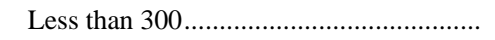 & 30 & 39 & 57 & 75 & 87 & 96 & 96 \\
\hline 300 to 999 & 35 & 52 & 66 & 78 & 89 & 94 & 98 \\
\hline 1,000 or more & 58 & 69 & 80 & 89 & 95 & 96 & 99 \\
\hline \multicolumn{8}{|l|}{ Metropolitan status } \\
\hline  & 40 & 47 & 64 & 74 & 92 & 93 & 96 \\
\hline Urban fringe & 38 & 59 & 75 & 78 & 85 & 96 & 98 \\
\hline Town & 29 & 47 & 61 & 84 & 90 & 94 & 98 \\
\hline 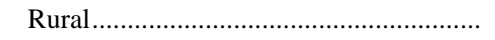 & 35 & 48 & 60 & 79 & 92 & 96 & 99 \\
\hline \multicolumn{8}{|l|}{ Percent minority enrollment ${ }^{2}$} \\
\hline 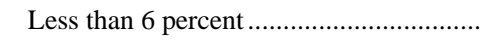 & 38 & 52 & 65 & 84 & 91 & 95 & 98 \\
\hline 6 to 20 percent & 38 & 58 & 72 & 87 & 93 & 97 & 100 \\
\hline 21 to 49 percent & 38 & 55 & 65 & 73 & 91 & 96 & 98 \\
\hline 50 percent or more & 27 & 39 & 56 & 63 & 82 & 92 & 96 \\
\hline \multicolumn{8}{|l|}{$\begin{array}{l}\text { Percent of students eligible for free or } \\
\text { reduced-price school lunch }\end{array}$} \\
\hline  & 39 & 60 & 74 & 86 & 92 & 95 & 99 \\
\hline 35 to 49 percent & 36 & 48 & 59 & 81 & 93 & 98 & 99 \\
\hline 50 to 74 percent & 31 & 41 & 53 & 71 & 88 & 96 & 97 \\
\hline 75 percent or more & 20 & 31 & 53 & 62 & 79 & 89 & 94 \\
\hline
\end{tabular}

${ }^{1}$ Data for combined schools are included in the totals and in analyses by other school characteristics but are not shown separately.

${ }^{2}$ Percent minority enrollment was not available for some cases. In 1994, this information was missing for 100 schools. In subsequent years, the missing information ranged from 46 schools (1995) to 6 (1997).

${ }^{3}$ The breakouts for the percentage of students eligible for free or reduced-price school lunch have been revised this year and therefore are different from the ones reported in previous Internet access reports.

${ }^{4}$ In this case, the estimate fell between 99.5 percent and 100 percent and therefore was rounded to 100 percent.

NOTE: All of the estimates in this report were recalculated from the raw data files using the same computational algorithms. Consequently, the estimates presented here may differ trivially (i.e., 1 percent) from previously published results.

SOURCE: U.S. Department of Education, National Center for Education Statistics, Fast Response Survey System, "Survey on Advanced Telecommunications in U.S. Public Schools, K-12," FRSS 51 (1994); "Survey on Advanced Telecommunications in U.S. Public Schools, K-12," FRSS 57 (1995); "Advanced Telecommunications in U.S. Public Schools, Fall 1996," FRSS 61; "Internet Access in U.S. Public Schools, Fall 1997," FRSS 64; "Internet Access in U.S. Public Schools, Fall 1998," FRSS 69; "Internet Access in U.S. Public Schools, Fall 1999," FRSS 75; and "Internet Access in U.S. Public Schools, Fall 2000," FRSS 79. 
Another key measure of Internet access in schools is the proportion of instructional rooms connected to the Internet. ${ }^{4}$ Since 1994, when 3 percent of instructional rooms had computers with Internet access, public schools have made consistent progress in this area: in fall 2000, 77 percent of instructional rooms were connected to the Internet, up from 64 percent in 1999 (table 2 ). However, in 2000 , as in previous years, there were differences in Internet access in instructional rooms by school characteristics. For example, in schools with the highest concentration of students in poverty ( 75 percent or more students eligible for free or reducedprice school lunch), a smaller percentage of instructional rooms were connected to the Internet (60 percent) than in schools with lower concentrations of poverty (77 to 82 percent of instructional rooms). A similar pattern occurred by minority enrollment. In schools with the highest minority enrollment (50 percent or more), a smaller percentage of instructional rooms had Internet access (64 percent) than in schools with lower minority enrollment (79 to 85 percent of instructional rooms). Despite these continuing differences, however, the percentage of instructional rooms with Internet access increased between 1999 and 2000 in these schools: from 38 to 60 percent in schools with the highest concentration of poverty, and from 43 to 64 percent in schools with the highest minority enrollment.

\section{What is the ratio of students to instructional computers in public schools?}

By the fall of 2000, the ratio of students to instructional computers in public schools had decreased to 5 to 1 , the ratio that "many experts consider . . . a reasonable level for the effective use of computers within the schools" (President's Committee of Advisors on Science and Technology 1997, p. 14). The ratio improved from a national average of 6 to 1 in 1999 (not shown in tables).

\footnotetext{
${ }^{4}$ Instructional rooms include classrooms, computer and other labs, library/media centers, and any other rooms used for instructional purposes.
}

Similarly, the ratio of students to instructional computers with Internet access in public schools improved from 9 to 1 in 1999 to 7 to 1 in 2000 (table 3). However, differences by school characteristics persisted. For example, the ratio of students to instructional computers with Internet access was still greater in schools with the highest concentration of students in poverty than in schools with the lowest concentration of poverty (9 to 1 compared with 6 to 1 ). Nonetheless, in schools with the highest concentration of poverty, the ratio of students to computers with Internet access improved from 17 to 1 in 1999 to 9 to 1 in 2000 .

\section{How are public schools connected to the Internet?}

Over the years, changes have occurred in the type of network connections used by public schools and the speed at which they are connected to the Internet. In 1996, dial-up Internet connections were used by almost threefourths (74 percent) of public schools having Internet access (Heaviside, Riggins, and Farris 1997). By 2000, schools tended to use faster dedicated-line Internet connections, such as $56 \mathrm{~Kb}, \mathrm{~T} 1 / \mathrm{DS} 1$, fractionalized $\mathrm{T} 1, \mathrm{~T} 3 / \mathrm{DS} 3$, and fractionalized T3 lines (table 4). Seventy-seven percent of the nation's public schools that were connected to the Internet used dedicated lines, 11 percent used dial-up (not continuous) connections, and 24 percent of schools used other (continuous) connection types, including ISDN, wireless connections, and cable modems. ${ }^{5}$ There were differences by instructional level; secondary schools (86 percent) were more likely to use dedicated lines than elementary schools (74 percent).

\footnotetext{
${ }^{5}$ Percentages add to more than 100 because schools may use more than one type of connection.
} 


\section{Table 2.-Percent of instructional rooms with Internet access in public schools, by school characteristics: $1994-2000$}

\begin{tabular}{|c|c|c|c|c|c|c|c|}
\hline \multirow{2}{*}{ School characteristic } & \multicolumn{7}{|c|}{ Instructional rooms with Internet access } \\
\hline & 1994 & 1995 & 1996 & 1997 & 1998 & 1999 & 2000 \\
\hline All public schools .............................. & 3 & 8 & 14 & 27 & 51 & 64 & 77 \\
\hline \multicolumn{8}{|l|}{ Instructional level $^{1}$} \\
\hline 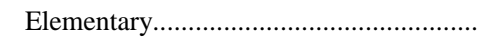 & 3 & 8 & 13 & 24 & 51 & 62 & 76 \\
\hline 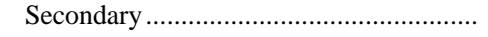 & 4 & 8 & 16 & 32 & 52 & 67 & 79 \\
\hline \multicolumn{8}{|l|}{ School size } \\
\hline 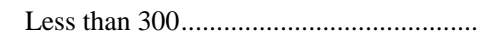 & 3 & 9 & 15 & 27 & 54 & 71 & 83 \\
\hline 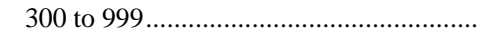 & 3 & 8 & 13 & 28 & 53 & 64 & 78 \\
\hline 1,000 or more & 3 & 4 & 16 & 25 & 45 & 58 & 70 \\
\hline
\end{tabular}

Metropolitan status

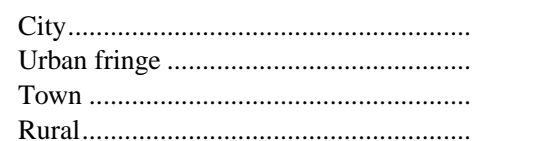

4
4
3
3

$\begin{array}{ll}6 & 12 \\ 8 & 1 \\ 8 & 14 \\ 8 & 14\end{array}$

12
16
14
14

20
29
34
30

47
50
55
57

$\begin{array}{ll}52 & 66 \\ 67 & 78 \\ 72 & 87 \\ 71 & 85\end{array}$

Percent minority enrollment ${ }^{2}$



4
4
4
2

$\begin{array}{rr}9 & 18 \\ 10 & 18 \\ 9 & 12 \\ 3 & \end{array}$

18
18
12
5

$\begin{array}{llll}37 & 57 & 74 & 85 \\ 35 & 59 & 78 & 83 \\ 22 & 52 & 64 & 79 \\ 13 & 37 & 43 & 64\end{array}$

Percent of students eligible for free or reduced-price school lunch ${ }^{3}$

\begin{tabular}{|c|c|c|c|c|c|c|c|}
\hline 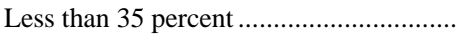 & 3 & 9 & 17 & 33 & 57 & 73 & 82 \\
\hline  & 2 & 6 & 12 & 33 & 60 & 69 & 81 \\
\hline $50-74$ percent & 4 & 6 & 11 & 20 & 41 & 61 & 77 \\
\hline 75 percent or more & 2 & 3 & 5 & 14 & 38 & 38 & 60 \\
\hline
\end{tabular}

${ }^{1}$ Data for combined schools are included in the totals and in analyses by other school characteristics but are not shown separately.

${ }^{2}$ Percent minority enrollment was not available for some cases. In 1994, this information was missing for 100 schools. In subsequent years, the missing information ranged from 46 schools (1995) to 6 (1997).

${ }^{3}$ The breakouts for the percentage of students eligible for free or reduced-price school lunch have been revised this year and therefore are different from the ones reported in previous Internet access reports.

NOTE: All of the estimates in this report were recalculated from the raw data files using the same computational algorithms. Consequently, the estimates presented here may differ trivially (i.e., 1 percent) from previously published results.

SOURCE: U.S. Department of Education, National Center for Education Statistics, Fast Response Survey System, "Survey on Advanced Telecommunications in U.S. Public Schools, K-12," FRSS 51 (1994); "Survey on Advanced Telecommunications in U.S. Public Schools, K-12," FRSS 57 (1995); "Advanced Telecommunications in U.S. Public Schools, Fall 1996," FRSS 61; "Internet Access in U.S. Public Schools, Fall 1997," FRSS 64; "Internet Access in U.S. Public Schools, Fall 1998," FRSS 69; "Internet Access in U.S. Public Schools, Fall 1999," FRSS 75; and "Internet Access in U.S. Public Schools, Fall 2000," FRSS 79. 


\begin{tabular}{|c|c|c|c|c|}
\hline \multirow[t]{2}{*}{ School characteristic } & \multicolumn{3}{|c|}{$\begin{array}{c}\text { Students per instructional } \\
\text { computers with Internet access }\end{array}$} & \multirow{2}{*}{$\begin{array}{l}\text { Internet available to } \\
\text { students outside of regular } \\
\text { school hours: } 2000\end{array}$} \\
\hline & 1998 & 1999 & 2000 & \\
\hline 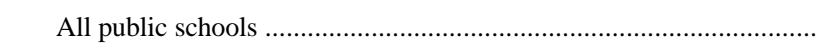 & 12 & 9 & 7 & 54 \\
\hline \multicolumn{5}{|l|}{ Instructional level $^{1}$} \\
\hline Elementary....................... & 14 & 11 & 8 & 46 \\
\hline Secondary …...................................... & 10 & 7 & 5 & 80 \\
\hline \multicolumn{5}{|l|}{ School size } \\
\hline 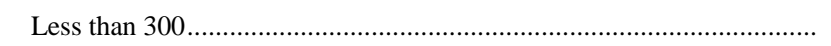 & 9 & 6 & 4 & 49 \\
\hline 300 to 999 & 12 & 9 & 7 & 53 \\
\hline 1,000 or more & 13 & 10 & 7 & 79 \\
\hline \multicolumn{5}{|l|}{ Metropolitan status } \\
\hline  & 14 & 11 & 8 & 56 \\
\hline Urban fringe & 13 & 9 & 7 & 58 \\
\hline Town & 12 & 8 & 6 & 45 \\
\hline 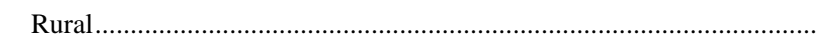 & 9 & 7 & 5 & 53 \\
\hline \multicolumn{5}{|l|}{ Minority enrollment ${ }^{2}$} \\
\hline Less than 6 percent & 10 & 7 & 6 & 46 \\
\hline 6 to 20 percent & 11 & 8 & 6 & 59 \\
\hline 21 to 49 percent & 12 & 9 & 7 & 54 \\
\hline 50 percent or more & 17 & 13 & 8 & 61 \\
\hline \multicolumn{5}{|l|}{$\begin{array}{l}\text { Students eligible for free or } \\
\text { reduced-price school lunch }\end{array}$} \\
\hline Less than 35 percent ................. & 11 & 8 & 6 & 58 \\
\hline 35 to 49 percent & 11 & 9 & 6 & 47 \\
\hline 50 to 74 percent & 16 & 10 & 7 & 52 \\
\hline 75 percent or more & 17 & 17 & 9 & 56 \\
\hline
\end{tabular}

${ }^{1}$ Data for combined schools are included in the totals and in analyses by other school characteristics but are not shown separately.

${ }^{2}$ Percent minority enrollment was not available for 9 schools in 1998 and 2000.

${ }^{3}$ The breakouts for the percentage of students eligible for free or reduced-price school lunch have been revised this year and therefore are different from the ones reported in previous Internet access reports.

NOTE: All of the estimates in this report were recalculated from the raw data files using the same computational algorithms. Consequently, the estimates presented here may differ trivially (i.e., 1 percent) from previously published results.

SOURCE: U.S. Department of Education, National Center for Education Statistics, Fast Response Survey System, "Internet Access in U.S. Public Schools, Fall 1998," FRSS 69; "Internet Access in U.S. Public Schools, Fall 1999," FRSS 75; and "Internet Access in U.S. Public Schools, Fall 2000," FRSS 79. 
To what extent are public schools making the Internet available to students outside of regular school hours in 2000 ?

Making the Internet accessible outside of regular school hours allows students who would not otherwise have access to the Internet to use this resource for school-related activities like homework. In 2000, 54 percent of public schools with access to the Internet reported that computers with access to the Internet were available to students outside of regular school hours (table 3). Secondary schools were more likely to make the Internet available to students outside of regular school hours than elementary schools (80 percent compared to 46 percent). Similarly, large schools (1,000 or more students) were more likely to make the Internet accessible

Table 4.- Percent of public schools with Internet access using the following types of connections, by school characteristics: 1998-2000

\begin{tabular}{|c|c|c|c|c|c|c|c|c|c|}
\hline \multirow{2}{*}{ School characteristic } & \multicolumn{3}{|c|}{ Dedicated line $^{1}$} & \multicolumn{3}{|c|}{ Dial-up connection } & \multicolumn{3}{|c|}{ Other types of connection ${ }^{2}$} \\
\hline & 1998 & 1999 & 2000 & 1998 & 1999 & 2000 & 1998 & 1999 & 2000 \\
\hline All public schools............................... & 65 & 72 & 77 & 22 & 15 & 11 & 26 & 23 & 24 \\
\hline \multicolumn{10}{|l|}{ Instructional level $^{3}$} \\
\hline 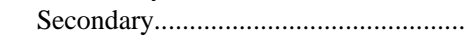 & 77 & 85 & 86 & 24 & 8 & 7 & 18 & 17 & 19 \\
\hline \multicolumn{10}{|l|}{ School size } \\
\hline  & 63 & 70 & 76 & 28 & 21 & 18 & 18 & 15 & 19 \\
\hline 300 to 999 . & 64 & 72 & 77 & 20 & 13 & 8 & 30 & 26 & 26 \\
\hline 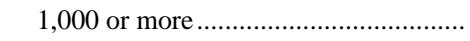 & 79 & 76 & 82 & 21 & 11 & 9 & 24 & 23 & 24 \\
\hline \multicolumn{10}{|l|}{ Metropolitan status } \\
\hline 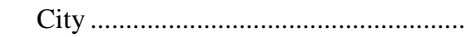 & 58 & 70 & 72 & 18 & 15 & 15 & 38 & 23 & 28 \\
\hline 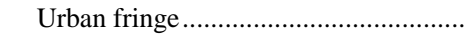 & 69 & 71 & 77 & 21 & 12 & 7 & 24 & 27 & 28 \\
\hline  & 65 & 71 & 77 & 24 & 14 & 13 & 28 & 24 & 19 \\
\hline  & 69 & 75 & 83 & 27 & 19 & 10 & 15 & 16 & 17 \\
\hline \multicolumn{10}{|l|}{ Percent minority enrollment ${ }^{4}$} \\
\hline 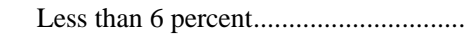 & 66 & 72 & 80 & 24 & 15 & 12 & 21 & 21 & 18 \\
\hline 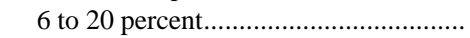 & 72 & 78 & 76 & 15 & 12 & 9 & 24 & 22 & 26 \\
\hline 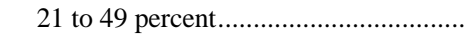 & 67 & 69 & 79 & 21 & 15 & 7 & 28 & 23 & 22 \\
\hline 50 percent or more & 56 & 68 & 74 & 28 & 18 & 15 & 36 & 24 & 28 \\
\hline \multicolumn{10}{|l|}{$\begin{array}{l}\text { Percent of students eligible for free or } \\
\text { reduced-price school lunch }\end{array}$} \\
\hline Less than 35 percent.............................. & 67 & 75 & 78 & 18 & 10 & 10 & 28 & 23 & 23 \\
\hline 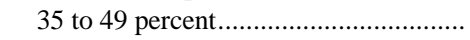 & 72 & 74 & 75 & 20 & 13 & 9 & 27 & 24 & 26 \\
\hline 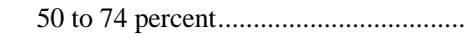 & 66 & 69 & 82 & 26 & 23 & 11 & 20 & 18 & 20 \\
\hline 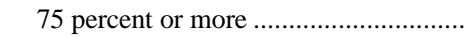 & 53 & 62 & 71 & 33 & 22 & 15 & 28 & 25 & 28 \\
\hline
\end{tabular}

${ }^{1}$ Includes 56Kb, T1/DS1, fractionalized T1, T3/DS3, and fractionalized T3 lines.

${ }^{2}$ Includes ISDN, wireless connections, and cable modems (generally continuous connections, similar to dedicated lines).

${ }^{3}$ Data for combined schools are included in the totals and in analyses by other school characteristics but are not shown separately.

${ }^{4}$ Percent minority enrollment was not available for 9 schools in 1998 and 2000.

${ }^{5}$ The breakouts for the percentage of students eligible for free or reduced-price school lunch have been revised this year and therefore are different from the ones reported in previous Internet access reports.

NOTE: Percentages are based on the percent of public school having Internet access: 89 percent in 1998,95 percent in 1999 , and 98 percent in 2000. Percentages add to more than 100 because schools may use more than one type of connection.

SOURCE: U.S. Department of Education, National Center for Education Statistics, Fast Response Survey System, "Internet Access in U.S. Public Schools, Fall 1998," FRSS 69; "Internet Access in U.S. Public Schools, Fall 1999," FRSS 75; and "Internet Access in U.S. Public Schools, Fall 2000," FRSS 79. 
to students outside of regular school hours than medium-sized and small schools (79 percent compared with 53 and 49 percent, respectively). In addition, schools with the highest minority enrollment reported Internet availability outside of regular school hours more frequently than schools with the lowest minority enrollment (61 percent compared with 46 percent). Of the 54 percent of schools making the Internet available to students outside of regular school hours, 98 percent made it available after school, 84 percent before school, and 16 percent on weekends (figure 1).

\section{Figure 1.-Percent of public schools allowing students to access the Internet outside of regular school hours giving students access after school, before school, and on weekends: 2000}

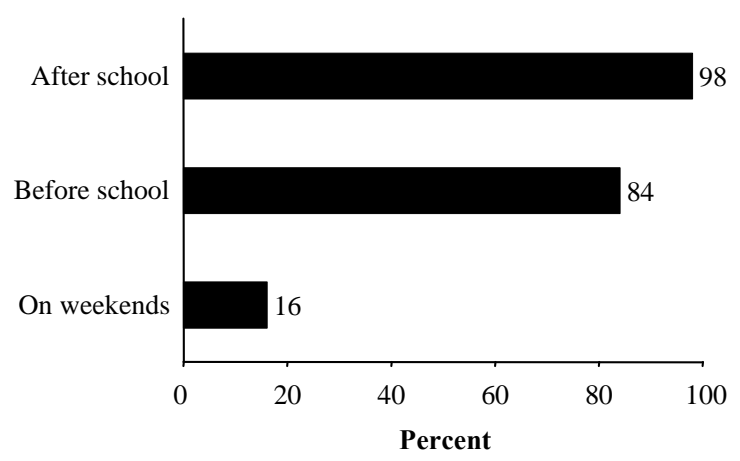

NOTE: Percentages are based on 53 percent of all public schools (98 percent with Internet access times 54 percent allowing students to access the Internet at times other than regular school hours). Percentages add to more than 100 because schools may have more than one time of availability.

SOURCE: U.S. Department of Education, National Center for Education Statistics, Fast Response Survey System, "Internet Access in U.S. Public Schools, Fall 2000,” FRSS 79.
How are public schools preventing students from accessing inappropriate material on the Internet in 2000?

Given the diversity of the information carried on the Internet, student access to inappropriate material is a major concern of many parents and teachers. In 2000, almost all public schools with Internet access (98 percent) had "acceptable use policies" (AUPs) and used various technologies or procedures, such as blocking or filtering software, an intranet system, honor codes for students, or teacher/staff monitoring, to control student access to inappropriate material on the Internet (not shown in tables). Across all types of schools, between 95 and 100 percent had AUPs. Of those schools with AUPs, 94 percent reported having student access to the Internet monitored by teachers or other staff members (figure 2). Three-fourths (74 percent) used blocking or filtering software, 64 percent had honor codes, and 28 percent used their intranet. As these numbers suggest, most of the schools (91 percent) used more than one procedure or technology as part of their policy (calculated from table 5). Fifteen percent of public schools

\section{Figure 2.-Percent of public schools having acceptable use policies (AUPs) using the following technologies or procedures: 2000}



NOTE: Percentages are based on 96 percent of all public schools (98 percent with Internet access times 98 percent having AUPs). Percentages add to more than 100 because schools may use more than one type of AUP.

SOURCE: U.S. Department of Education, National Center for Education Statistics, Fast Response Survey System, "Internet Access in U.S. Public Schools, Fall 2000," FRSS 79. 
used all of the procedures and technologies listed above; 29 percent used blocking/filtering software, teacher/staff monitoring, and honor codes; and 19 percent used blocking/filtering software and teacher/staff monitoring (table 5). In addition, 95 percent of public schools having AUPs used at least one of these technologies or procedures on all Internet-connected computers used by students (not shown in tables).

\section{Methodology}

The Fast Response Survey System (FRSS) was established in 1975 by the National Center for Education Statistics (NCES), U.S. Department of Education. FRSS is designed to collect small amounts of issue-oriented data with minimal burden on respondents and with a relatively short timeframe.

The sample of elementary and secondary schools for the FRSS survey on Internet access in public schools was selected from the 19971998 NCES Common Core of Data (CCD) Public School Universe File, the most up-to-date file available at the time the sample was drawn.
Over 84,000 regular schools are contained in the 1997-1998 CCD Public School Universe File. For this survey, regular elementary and secondary/combined schools were selected. Special education, vocational education, and alternative schools were excluded from the sampling frame, along with schools with a highest grade below first grade and those outside the 50 states and the District of Columbia. With these exclusions, the final sampling frame consisted of about 81,400 schools, of which about 61,000 were classified as "elementary" schools and about 20,400 as "secondary/ combined" schools.

A sample of 1,218 schools was selected from the public school frame. To select the sample, the frame of schools was stratified by instructional level (elementary and secondary/combined schools), enrollment size class (less than 300 students, 300 to $999,1,000$ to 1,499 , and 1,500 or more), and percentage of students eligible for free or reduced-price lunch (less than 35 percent, 35 to 49 percent, 50 to 74 percent, 75 percent or more). Schools in the highest poverty category (schools with 75 percent or more students

\section{Table 5.-Percent of public schools with acceptable use policies (AUPs) using various combinations of procedures and/or technologies to prevent student access to inappropriate material on the Internet: 2000}

\begin{tabular}{|c|c|}
\hline Combination of four procedures and/or technologies & Percent \\
\hline 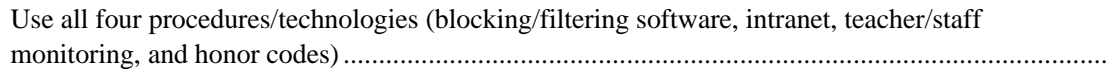 & 15 \\
\hline Use three procedures/technologies & 40 \\
\hline 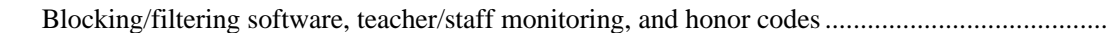 & 29 \\
\hline 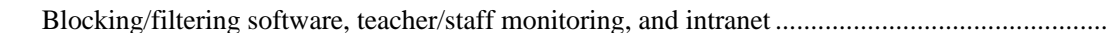 & 7 \\
\hline Others & 4 \\
\hline 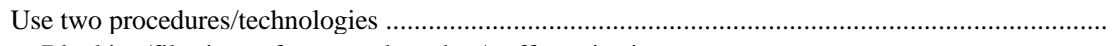 & 36 \\
\hline 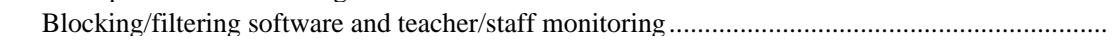 & 19 \\
\hline Teacher/staff monitoring and honor codes & 15 \\
\hline Others & 2 \\
\hline 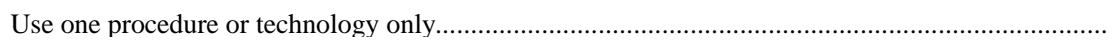 & 9 \\
\hline Teacher/staff monitoring.......................... & 5 \\
\hline Blocking/filtering software........................... & 3 \\
\hline 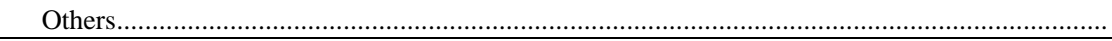 & 1 \\
\hline
\end{tabular}

NOTE: Percentages are based on 96 percent of all public schools (98 percent with Internet access times 98 percent having AUPs).

SOURCE: U.S. Department of Education, National Center for Education Statistics, Fast Response Survey System, "Internet Access in U.S. Public Schools, Fall 2000,” FRSS 79. 
eligible for free or reduced-price lunch) were oversampled to permit analyses for that category.

The two-page survey instrument was designed by Westat and NCES. The questions included on the survey addressed access to Internet in public schools and classrooms, the types of Internet connections used, student access to the Internet outside of regular school hours, and acceptable use policies.

In September 2000, questionnaires were mailed to the principals of the 1,218 sampled schools. The principal was asked to forward the questionnaire to the person at the school most knowledgeable about Internet access and other advanced telecommunications offered at the school. Telephone followup of nonrespondents was initiated in early October, and data collection was completed in December. Six schools were closed, two were outside the scope of the survey, and 1,104 schools completed the survey. Thus, the final response rate was 90.6 percent (1,104 of 1,210 eligible schools). The weighted response rate was 90.7 percent. The weighted nonresponse rate for individual questionnaire items ranged from 0 to 1.3 percent; imputation for item nonresponse was not implemented.

The survey responses were weighted to produce national estimates (table A). The weights were designed to adjust for the variable probabilities of selection and differential nonresponse. The findings in this report are based on the sample selected and, consequently, are subject to sampling variability. The standard error is the measure of the variability of estimates due to sampling. It indicates the variability of a sample estimate that would be obtained from all possible samples of a given design and size. Standard errors are used as a measure of the precision expected from a particular sample. If all possible samples were surveyed under similar conditions, intervals of 1.96 standard errors below to 1.96 standard errors above a particular statistic would include the true population parameter being estimated in about 95 percent of the samples. This is a 95 percent confidence interval. For example, the estimated percentage of public schools with Internet access in 2000 is 98 percent, and the estimated standard error is 0.5 percent. The 95 percent confidence interval for the statistics extends from $98-(0.5$ times 1.96) to $98+(0.5$ times 1.96$)$, or from 97 to 99 percent. Estimates of standard errors for this report were computed using a technique known as the jackknife replication method (standard error tables are found in the appendix). All specific statements of comparison made in this report have been tested for statistical significance using chi-square tests and t-tests adjusted for multiple comparisons using the Bonferroni adjustment and are significant at the 95 percent confidence level or better. However, not all significant differences are reported.

The survey estimates are also subject to nonsampling errors that can arise because of nonobservation (nonresponse or noncoverage) errors, errors of reporting, and errors made in collection of the data. These errors can sometimes bias the data. Nonsampling errors may include such problems as the difference in the respondents' interpretation of the meaning of the question; memory effects; misrecording of responses; incorrect editing, coding, or data entry; differences related to the particular time the survey was conducted; or errors in data preparation. While general sampling theory can be used in part to determine how to estimate the sampling variability of a statistic, nonsampling errors are not easy to measure and, for measurement purposes, usually require that an experiment be conducted as part of the data collection procedures or that data external to the study be used. To minimize the potential for nonsampling errors, the questionnaire on Internet access in public schools was pretested in 1994, and again each time it was substantially modified. The pretesting was done with public school technology coordinators and other knowledgeable respondents like those who completed the survey. No pretesting was necessary in 2000. During the design of the survey, an effort was made to check for consistency of interpretation of questions and to eliminate ambiguous items. The questionnaire and instructions were intensively reviewed by 


\section{Table A.-Number and percent of responding public schools in the study sample and estimated number and percent of public schools the sample represents, by school characteristics: 2000}

\begin{tabular}{l|l|l|l|c}
\hline \multirow{2}{*}{ School characteristic } & \multicolumn{2}{|c|}{ Respondent sample } & \multicolumn{3}{|c}{ National estimate } \\
\cline { 2 - 5 } & Number & Percent & Number & Percent \\
\hline
\end{tabular}

All public schools.

Instructional level

Elementary

Secondary

School size

Less than 300.

300 to 999

1,000 or more

Metropolitan status

City.

Urban fringe

Town

Rural

Percent minority enrollment

Percent minority enrollment
1,104
100
80,127
100

\begin{tabular}{|c|c|c|c|}
\hline Less than 6 percent & 280 & 26 & 25,083 \\
\hline 6 to 20 percent.. & 244 & 22 & 19,017 \\
\hline 21 to 49 percent ......... & 214 & 20 & 15,481 \\
\hline 50 percent or more & 357 & 33 & 19,856 \\
\hline
\end{tabular}

Percent of students eligible for free or

reduced-price school lunch

\begin{tabular}{|c|c|c|c|c|}
\hline Less than 35 percent & 490 & 44 & 36,563 & 46 \\
\hline 35 to 49 percent .............. & 161 & 15 & 12,414 & 16 \\
\hline 50 to 74 percent ....... & 205 & 19 & 17,030 & 21 \\
\hline 75 percent or more..... & 245 & 22 & 13,912 & 17 \\
\hline
\end{tabular}

NOTE: Details may not add to totals because of rounding on missing data. There were very small amounts of missing data for the following variables: percent minority enrollment in school ( 9 cases) and percent of students eligible for free or reduced-price lunch ( 3 cases). Forty schools were combined schools and therefore are missing in the instructional level counts used here, but those cases were included in the totals and in analysis by other school characteristics.

SOURCE: U.S. Department of Education, National Center for Education Statistics, Fast Response Survey System, "Internet Access in U.S. Public Schools, Fall 2000," FRSS 79, 2000. 
the National Center for Education Statistics. Manual and machine editing of the questionnaire responses were conducted to check the data for accuracy and consistency. Cases with missing or inconsistent items were recontacted by telephone to resolve problems. Data were keyed with 100 percent verification.

The survey was performed under contract with Westat, using the NCES Fast Response Survey System (FRSS). Westat's Project Director was Elizabeth Farris, and the Survey Manager was Anne Cattagni. Catrina Williams was the Survey Manager during the design phase of the survey. Bernie Greene was the NCES Project Officer.

To obtain definitions of terms for this Statistics in Brief, a copy of the questionnaire, or additional information about the Fast Response Survey System or the FRSS Internet surveys, contact Bernie Greene at NCES, 202-502-7348. To order additional copies of this Statistics in Brief or other NCES publications, call 1-800424-1616. NCES publications are also available on the Internet (http://www.nces.ed.gov/pub search).

This report was reviewed by the following individuals:

\section{Outside NCES:}

- Stephanie Cronen, American Institutes for Research

- Laura Johns, Office of Educational Technology, U.S. Department of Education

- Lawrence Lanahan, American Institutes for Research

- Jackie Shrago, Tennessee Department of Education

\section{Inside NCES:}

- Arnold Goldstein, Analysis and Reporting Program Assessment Division
- Bill Hussar, Early Childhood, International, and Crosscutting Studies Division

- Paula Knepper, Postsecondary Studies Division

- Marilyn McMillen, Chief Statistician

- Valena Plisko, Associate Commissioner, Early Childhood, International, and Crosscutting Studies Division

- Susan Wiley, Elementary/Secondary and Libraries Studies Division

\section{Related information}

This survey is part of an overall NCES effort to track the availability and use of technology in schools. The references below contain the source information about publications for the series of public school surveys on advanced telecommunications and Internet access. In addition to collecting information from public schools, NCES surveyed private schools about advanced telecommunications in 1995 and 1999. NCES has also collected information on teachers' use of technology. A report on this topic was released in summer 2000.

\section{References and related reports}

Bare, J., and Meek, A. 1998. Internet Access in Public Schools (NCES 98-031). U.S. Department of Education, National Center for Education Statistics. Washington, DC: U.S. Government Printing Office.

Heaviside, S., and Farris, E. 1997. Advanced Telecommunications in U.S. Private Schools, K-12, Fall 1995 (NCES 97-394). U.S. Department of Education, National Center for Education Statistics. Washington, DC: U.S. Government Printing Office.

Heaviside, S., Farris, E., and Malitz, G. 1995. Advanced Telecommunications in U.S. Public Schools, K-12 (NCES 95-731). U.S. Department of Education, National Center for 
Education Statistics. Washington, DC: U.S. Government Printing Office.

Heaviside, S., Farris, E., and Malitz, G. 1996. Advanced Telecommunications in U.S. Public Elementary and Secondary Schools, 1995 (NCES 96-854). U.S. Department of Education, National Center for Education Statistics. Washington, DC: U.S. Government Printing Office.

Heaviside S., Riggins, T., and Farris, E. 1997. Advanced Telecommunications in U.S. Public Elementary and Secondary Schools, Fall 1996 (NCES 97-944). U.S. Department of Education, National Center for Education Statistics. Washington, DC: U.S. Government Printing Office.

Heaviside, S., Rowand, C., Hurst, D., and McArthur, E. 2000. What Are the Barriers to the Use of Advanced Telecommunications for Students with Disabilities in Public Schools? (NCES 2000-042). U.S. Department of Education, National Center for Education Statistics. Washington, DC: U.S. Government Printing Office.

Levin, D., Hurst, D., and Burns, S. 2000. Computer and Internet Access in U.S. Private Schools and Classrooms: 1995 and 1998 (NCES 2000-044). U.S. Department of Education, National Center for Education Statistics. Washington, DC: U.S. Government Printing Office.
President's Committee of Advisors on Science and Technology, Panel on Educational Technology. 1997. Report to the President on the Use of Technology to Strengthen K-12 Education in the United States. This report is available online (http://www.ostp.gov/PCAST/ K-12ed.html).

Riley, R., Holleman, F., and Roberts, L. 2000. eLearning: Putting a World-Class Education at the Fingertips of All Children.U.S. Department of Education, Office of Educational Technology. This document is available online (http://www.ed.gov/ Technology/elearning/e-learning.pdf).

Rowand, C. 1999. Internet Access in Public Schools and Classrooms: 1994-98 (NCES 1999-017). U.S. Department of Education, National Center for Education Statistics. Washington, DC: U.S. Government Printing Office.

Smerdon, B., Cronen, S., Lanahan, L., Anderson, J., Iannotti, N., and Angeles, J. 2000. Teachers' Tools for the 21st Century: A Report on Teachers' Use of Technology (NCES 2000-102). U.S. Department of Education, National Center for Education Statistics. Washington, DC: U.S. Government Printing Office.

Williams, C. 2000. Internet Access in Public Schools and Classrooms: 1994-99 (NCES 2000-086). U.S. Department of Education, National Center for Education Statistics. Washington, DC: U.S. Government Printing Office. 
Appendix

Standard Error Tables 


\section{Table 1a.-Standard errors of the percent of public schools with Internet access, by school characteristics: 1994-2000}

\begin{tabular}{|c|c|c|c|c|c|c|c|}
\hline \multirow{2}{*}{ School characteristic } & \multicolumn{7}{|c|}{ Public schools with Internet access } \\
\hline & 1994 & 1995 & 1996 & 1997 & 1998 & 1999 & 2000 \\
\hline All public schools ................................. & 1.5 & 1.8 & 1.8 & 1.5 & 1.3 & 0.8 & 0.5 \\
\hline \multicolumn{8}{|l|}{ Instructional level } \\
\hline 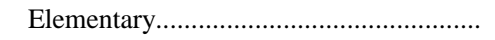 & 1.9 & 2.4 & 2.1 & 2.0 & 1.6 & 1.0 & 0.7 \\
\hline Secondary & 2.4 & 2.7 & 1.8 & 1.7 & 2.1 & 0.8 & 0.2 \\
\hline \multicolumn{8}{|l|}{ School size } \\
\hline 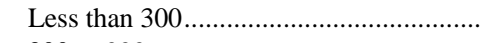 & 3.4 & 3.9 & 4.4 & 3.8 & 3.4 & 1.5 & 1.7 \\
\hline 300 to 999 & 2.0 & 2.2 & 2.0 & 2.0 & 1.4 & 1.0 & 0.5 \\
\hline 1,000 or more & 3.0 & 4.1 & 3.4 & 2.5 & 2.4 & 1.7 & 0.6 \\
\hline \multicolumn{8}{|l|}{ Metropolitan status } \\
\hline 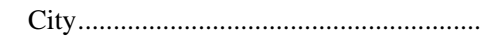 & 3.1 & 4.3 & 4.5 & 3.8 & 2.1 & 1.5 & 1.1 \\
\hline Urban fringe & 2.9 & 3.8 & 3.3 & 2.8 & 2.8 & 1.2 & 1.2 \\
\hline Town & 2.3 & 3.7 & 4.0 & 4.6 & 3.2 & 2.5 & 1.2 \\
\hline  & 2.7 & 3.8 & 3.3 & 3.2 & 3.4 & 1.4 & 0.9 \\
\hline \multicolumn{8}{|l|}{ Percent minority enrollment } \\
\hline Less than 6 percent & 2.4 & 3.2 & 3.4 & 2.7 & 2.9 & 1.5 & 1.2 \\
\hline 6 to 20 percent & 3.3 & 4.7 & 3.0 & 2.7 & 2.5 & 1.2 & $(+)$ \\
\hline 21 to 49 percent & 3.2 & 4.1 & 3.2 & 4.1 & 2.5 & 1.8 & 1.2 \\
\hline 50 percent or more & 2.9 & 3.8 & 4.6 & 4.7 & 2.9 & 1.9 & 1.2 \\
\hline \multicolumn{8}{|l|}{$\begin{array}{l}\text { Percent of students eligible for free or } \\
\text { reduced-price school lunch }\end{array}$} \\
\hline 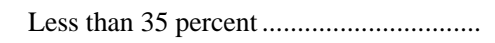 & 2.4 & 2.4 & 2.3 & 1.8 & 2.0 & 1.1 & 0.7 \\
\hline 35 to 49 percent & 4.9 & 3.9 & 4.8 & 3.9 & 2.2 & 0.9 & 0.7 \\
\hline 50 to 74 percent & 5.0 & 4.6 & 5.1 & 4.0 & 3.0 & 1.7 & 1.3 \\
\hline 75 percent or more & 4.9 & 4.4 & 5.5 & 5.3 & 3.7 & 3.1 & 1.7 \\
\hline
\end{tabular}

(+) Estimate of standard error is not derived because it is based on a statistic estimated at 100 percent.

SOURCE: U.S. Department of Education, National Center for Education Statistics, Fast Response Survey System, "Survey on Advanced Telecommunications in U.S. Public Schools, K-12," FRSS 51 (1994); "Survey on Advanced Telecommunications in U.S. Public Schools, K-12," FRSS 57 (1995); "Advanced Telecommunications in U.S. Public Schools, Fall 1996," FRSS 61; "Internet Access in U.S. Public Schools, Fall 1997," FRSS 64; "Internet Access in U.S. Public Schools, Fall 1998," FRSS 69; "Internet Access in U.S. Public Schools, Fall 1999," FRSS 75; and "Internet Access in U.S. Public Schools, Fall 2000," FRSS 79. 


\section{Table 2a.-Standard errors of the percent of instructional rooms with Internet access in public schools, by school characteristics: 1994-2000}

\begin{tabular}{|c|c|c|c|c|c|c|c|}
\hline \multirow{2}{*}{ School characteristic } & \multicolumn{7}{|c|}{ Instructional rooms with Internet access } \\
\hline & 1994 & 1995 & 1996 & 1997 & 1998 & 1999 & 2000 \\
\hline All public schools ................................... & 0.3 & 0.7 & 1.0 & 1.6 & 1.8 & 1.6 & 1.1 \\
\hline \multicolumn{8}{|l|}{ Instructional level } \\
\hline 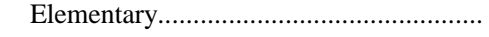 & 0.4 & 1.0 & 1.5 & 1.9 & 2.3 & 1.8 & 1.5 \\
\hline 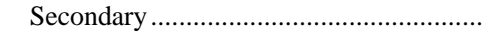 & 0.6 & 1.0 & 1.5 & 1.9 & 2.1 & 2.6 & 1.6 \\
\hline \multicolumn{8}{|l|}{ School size } \\
\hline 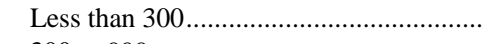 & 0.7 & 1.6 & 2.9 & 4.3 & 3.7 & 3.2 & 2.8 \\
\hline 300 to $999 .$. & 0.5 & 1.0 & 1.2 & 2.0 & 2.2 & 1.9 & 1.5 \\
\hline 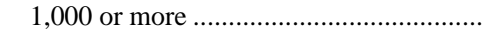 & 0.6 & 1.0 & 2.1 & 2.4 & 3.9 & 3.0 & 2.2 \\
\hline \multicolumn{8}{|l|}{ Metropolitan status } \\
\hline 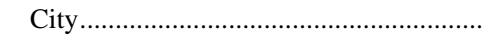 & 0.8 & 1.3 & 1.6 & 2.2 & 3.2 & 2.6 & 2.2 \\
\hline Urban fringe ..................................... & 0.8 & 1.4 & 2.2 & 2.9 & 2.9 & 2.5 & 2.0 \\
\hline 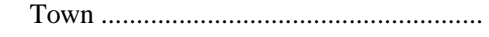 & 0.6 & 2.0 & 1.9 & 3.9 & 4.0 & 3.4 & 2.6 \\
\hline 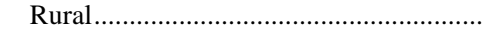 & 0.4 & 1.5 & 2.2 & 3.6 & 3.6 & 3.0 & 1.7 \\
\hline \multicolumn{8}{|l|}{ Percent minority enrollment } \\
\hline  & 0.7 & 1.4 & 2.4 & 3.5 & 2.7 & 2.3 & 1.9 \\
\hline 6 to 20 percent .................................... & 0.8 & 1.5 & 1.7 & 3.0 & 3.3 & 3.1 & 2.1 \\
\hline 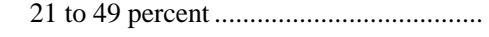 & 1.0 & 2.1 & 2.5 & 2.8 & 3.7 & 3.1 & 2.3 \\
\hline 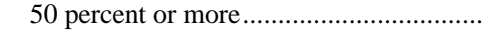 & 0.3 & 1.0 & 1.8 & 1.8 & 3.2 & 2.8 & 2.4 \\
\hline \multicolumn{8}{|l|}{$\begin{array}{l}\text { Percent of students eligible for free or } \\
\text { reduced-price school lunch }\end{array}$} \\
\hline 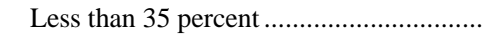 & 0.5 & 1.1 & 1.6 & 2.0 & 2.4 & 2.3 & 1.5 \\
\hline 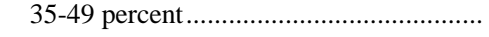 & 0.5 & 1.4 & 2.2 & 4.3 & 5.1 & 3.4 & 2.9 \\
\hline 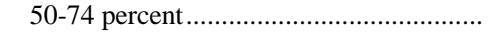 & 1.9 & 1.9 & 2.8 & 3.7 & 3.9 & 3.1 & 2.8 \\
\hline  & 1.0 & 1.0 & 1.8 & 2.4 & 4.3 & 4.4 & 3.3 \\
\hline
\end{tabular}

SOURCE: U.S. Department of Education, National Center for Education Statistics, Fast Response Survey System, "Survey on Advanced Telecommunications in U.S. Public Schools, K-12," FRSS 51 (1994); "Survey on Advanced Telecommunications in U.S. Public Schools, K-12," FRSS 57 (1995); "Advanced Telecommunications in U.S. Public Schools, Fall 1996," FRSS 61; "Internet Access in U.S. Public Schools, Fall 1997," FRSS 64; "Internet Access in U.S. Public Schools, Fall 1998," FRSS 69; "Internet Access in U.S. Public Schools, Fall 1999," FRSS 75; and "Internet Access in U.S. Public Schools, Fall 2000," FRSS 79. 


\begin{tabular}{|c|c|c|c|c|}
\hline \multicolumn{5}{|c|}{$\begin{array}{r}\text { Table 3a.- Standard errors of the ratio of students to instructional computers with Internet } \\
\text { access in public schools, and percent of public schools allowing students to access the } \\
\text { Internet outside of regular school hours, by school characteristics: } 1998-2000\end{array}$} \\
\hline \multirow[t]{2}{*}{ School characteristic } & \multicolumn{3}{|c|}{$\begin{array}{c}\text { Students per instructional } \\
\text { computers with Internet access }\end{array}$} & \multirow{2}{*}{$\begin{array}{l}\text { Internet available to } \\
\text { students outside of regular } \\
\text { school hours: } 2000 \\
\end{array}$} \\
\hline & 1998 & 1999 & 2000 & \\
\hline All public schools ................... & 0.6 & 0.3 & 0.1 & 1.9 \\
\hline \multicolumn{5}{|l|}{ Instructional level } \\
\hline Elementary & 1.0 & 0.4 & 0.2 & 2.6 \\
\hline Secondary & 0.5 & 0.3 & 0.2 & 1.9 \\
\hline \multicolumn{5}{|l|}{ School size } \\
\hline Less than $300 \ldots$ & 0.7 & 0.4 & 0.3 & 4.1 \\
\hline 300 to 999 & 0.7 & 0.4 & 0.2 & 2.2 \\
\hline 1,000 or more & 1.1 & 0.6 & 0.3 & 3.2 \\
\hline \multicolumn{5}{|l|}{ Metropolitan status } \\
\hline 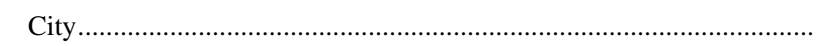 & 1.2 & 0.8 & 0.4 & 3.8 \\
\hline Urban fringe ..................... & 1.0 & 0.4 & 0.2 & 2.8 \\
\hline Town ......................... & 1.2 & 0.6 & 0.3 & 4.6 \\
\hline 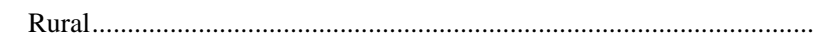 & 0.9 & 0.4 & 0.3 & 3.4 \\
\hline \multicolumn{5}{|l|}{ Minority enrollment } \\
\hline Less than 6 percent .......... & 0.6 & 0.3 & 0.2 & 3.5 \\
\hline 6 to 20 percent & 1.1 & 0.5 & 0.2 & 3.8 \\
\hline 21 to 49 percent & 1.2 & 0.7 & 0.3 & 3.6 \\
\hline 50 percent or more & 1.7 & 1.1 & 0.4 & 3.2 \\
\hline \multicolumn{5}{|l|}{ Students eligible for free or reduced-price school lunch } \\
\hline Less than 35 percent & 0.6 & 0.3 & 0.2 & 2.8 \\
\hline 35 to 49 percent & 1.2 & 0.4 & 0.4 & 4.3 \\
\hline 50 to 74 percent & 1.4 & 0.8 & 0.4 & 4.1 \\
\hline 75 percent or more & 2.5 & 2.2 & 0.7 & 4.1 \\
\hline
\end{tabular}

SOURCE: U.S. Department of Education, National Center for Education Statistics, Fast Response Survey System, "Internet Access in U.S. Public Schools, Fall 1998," FRSS 69; "Internet Access in U.S. Public Schools, Fall 1999," FRSS 75; and "Internet Access in U.S. Public Schools, Fall 2000," FRSS 79. 


\section{Table 4a.--Standard errors of the percent of public schools with Internet access using the following types of connections by school characteristics: 1998-2000}

\begin{tabular}{|c|c|c|c|c|c|c|c|c|c|}
\hline \multirow{2}{*}{ School characteristic } & \multicolumn{3}{|c|}{ Dedicated line } & \multicolumn{3}{|c|}{ Dial-up connection } & \multicolumn{3}{|c|}{ Other types of connection } \\
\hline & 1998 & 1999 & 2000 & 1998 & 1999 & 2000 & 1998 & 1999 & 2000 \\
\hline All public schools ............................. & 1.6 & 1.6 & 1.5 & 1.6 & 1.6 & 1.2 & 1.6 & 1.3 & 1.5 \\
\hline \multicolumn{10}{|l|}{ Instructional level } \\
\hline 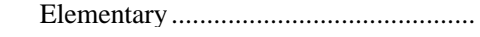 & 2.2 & 2.0 & 2.0 & 2.0 & 2.0 & 1.7 & 2.1 & 1.6 & 1.9 \\
\hline  & 2.1 & 2.1 & 1.8 & 2.5 & 1.5 & 1.2 & 1.8 & 2.1 & 2.4 \\
\hline \multicolumn{10}{|l|}{ School size } \\
\hline 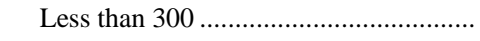 & 4.0 & 3.6 & 3.8 & 3.7 & 3.6 & 3.4 & 3.3 & 3.4 & 3.4 \\
\hline 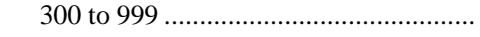 & 2.3 & 1.9 & 1.7 & 2.1 & 1.7 & 1.2 & 2.1 & 1.7 & 1.9 \\
\hline 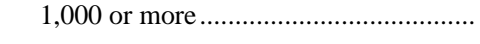 & 3.6 & 3.1 & 3.0 & 3.4 & 2.1 & 2.1 & 3.8 & 3.0 & 3.3 \\
\hline \multicolumn{10}{|l|}{ Metropolitan status } \\
\hline City & 4.4 & 4.0 & 2.8 & 2.8 & 2.7 & 3.0 & 4.9 & 3.2 & 2.4 \\
\hline 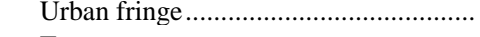 & 3.3 & 2.8 & 2.8 & 2.4 & 2.1 & 1.6 & 3.3 & 2.6 & 3.0 \\
\hline Town & 5.0 & 4.6 & 4.3 & 4.3 & 4.0 & 3.9 & 4.3 & 4.4 & 3.2 \\
\hline 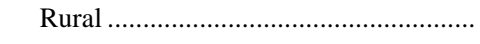 & 3.5 & 3.7 & 2.9 & 3.7 & 3.4 & 2.5 & 2.4 & 2.9 & 2.7 \\
\hline
\end{tabular}

Percent minority enrollment

\begin{tabular}{|c|c|c|c|c|c|c|c|c|}
\hline 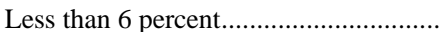 & 2.9 & 2.7 & 3.0 & 3.3 & 2.8 & 2.3 & 2.3 & 2.9 \\
\hline 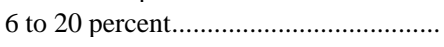 & 4.1 & 3.5 & 3.5 & 2.9 & 2.9 & 2.6 & 4.0 & 3.5 \\
\hline 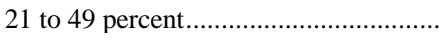 & 4.0 & 3.9 & 2.9 & 3.7 & 2.9 & 2.0 & 3.9 & 3.0 \\
\hline 50 percent or more & 4.7 & 3.5 & 3.1 & 3.6 & 2.9 & 2.6 & 5.1 & 2.9 \\
\hline
\end{tabular}

Percent of students eligible for free or reduced-price school lunch

\begin{tabular}{|c|c|c|c|c|c|c|c|c|c|}
\hline Less than 35 percent.............................. & 2.7 & 2.2 & 2.2 & 2.1 & 1.7 & 1.6 & 2.5 & 2.0 & 2.3 \\
\hline 35 to 49 percent ........................................ & 5.3 & 3.8 & 4.5 & 4.0 & 2.7 & 2.9 & 4.3 & 3.6 & 3.8 \\
\hline 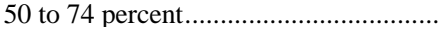 & 4.3 & 4.7 & 3.3 & 4.1 & 4.4 & 2.6 & 3.9 & 3.5 & 3.5 \\
\hline 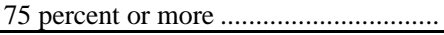 & 5.7 & 5.1 & 3.5 & 5.4 & 4.5 & 2.8 & 6.0 & 3.9 & 3.1 \\
\hline
\end{tabular}

SOURCE: U.S. Department of Education, National Center for Education Statistics, Fast Response Survey System, "Internet Access in U.S. Public Schools, Fall 1998," FRSS 69; "Internet Access in U.S. Public Schools, Fall 1999," FRSS 75; and "Internet Access in U.S. Public Schools, Fall 2000," FRSS 79. 


\begin{tabular}{|c|c|}
\hline $\begin{array}{l}\text { able 5a.- Standard errors of the percent of public schools with ac } \\
\text { using various combinations of procedures and/or technolo } \\
\text { to inappropriate material on the Internet: } 2000\end{array}$ & $\begin{array}{l}\text { use policies (AUPs) } \\
\text { revent student access }\end{array}$ \\
\hline Combination of procedures and/or technologies & Standard error \\
\hline $\begin{array}{l}\text { Use all four procedures/technologies (blocking/filtering software, intranet, } \\
\text { teacher/staff monitoring, honor codes) }\end{array}$ & 1.4 \\
\hline  & 1.9 \\
\hline 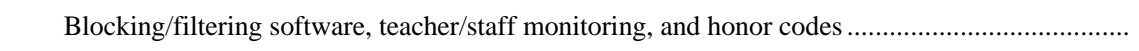 & 1.8 \\
\hline Blocking/filtering software, teacher/staff monitoring, and intranet.. & 1.0 \\
\hline Others........... & 0.6 \\
\hline 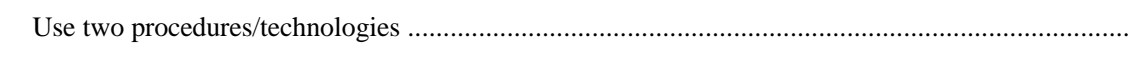 & 1.9 \\
\hline Blocking/filtering software and teacher/staff monitoring ........ & 1.5 \\
\hline Teacher/staff monitoring and honor codes ......... & 1.4 \\
\hline Others ............................................... & 0.6 \\
\hline 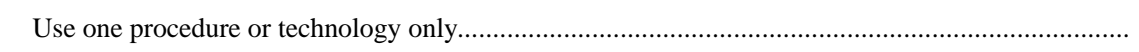 & 1.1 \\
\hline 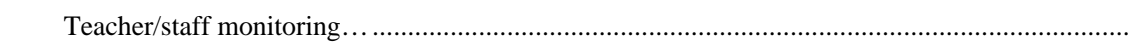 & 0.8 \\
\hline 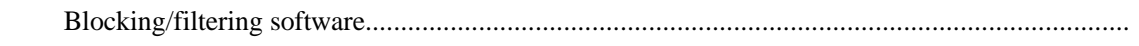 & 0.6 \\
\hline 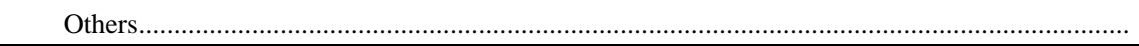 & 0.5 \\
\hline
\end{tabular}

SOURCE: U.S. Department of Education, National Center for Education Statistics, Fast Response Survey System, "Internet Access in U.S. Public Schools, Fall 2000," FRSS 79. 


\section{Table 6a.--Standard errors for the figures and for data not shown in tables}

$$
\text { Item }
$$

Figure 1: Percent of public schools allowing students to access the Internet outside of regular school hours giving students access after school, before school, and on weekends: 2000

Before school

On weekends

Figure 2: Percent of the public schools having acceptable use policies (AUPs) using the following technologies or procedures: 2000

Teacher/staff monitoring

Blocking/filtering software

Honor codes

Intranet

Section: What is the ratio of students to instructional computers in public schools?

Ratio of students to instructional computers in public schools in 1999

Section: How are public schools preventing students from accessing inappropriate material on the Internet in 2000?

Of the public schools with Internet access, percent having AUPs in 2000.

Of the public schools having AUPs, percent using at least one technology or procedure on all Internet-connected computers used by students in 2000 . 